MATEC Web of Conferences 13, 02002 (2014)

DOI: $10.1051 /$ matecconf/ 20141302002

(C) Owned by the authors, published by EDP Sciences, 2014

\title{
Effect of Operation Strategies on the Economic Performance of a Hybrid Photovoltaic-Micro Gas Turbine Trigeneration System
}

\author{
F. Basrawi ${ }^{1, a}$, H. Ibrahim ${ }^{1}$, M.R.R Chand ${ }^{1}$ and T. Yamada ${ }^{2}$ \\ ${ }^{1}$ Universiti Malaysia Pahang, Faculty of Mechanical Engineering, 26600 Pekan Pahang, Malaysia \\ ${ }^{2}$ Kitami Institute of Technology, Mechanical Engineering, Kitami City, Hokkaido 090-8507, Japan
}

\begin{abstract}
This study presents the economic performance of a photovoltaic (PV) and micro gas turbine trigeneration system (MGT-TGS) based hybrid energy system with various operation strategies. The hybrid system covers power, heating and cooling load of a selected building located in a tropical region. The core prime mover of each operation strategy is an MGT with power output capacity of $30 \mathrm{~kW}$ or $65 \mathrm{~kW}$. An energy balance analysis was conducted and the economic performance of each operation strategy was analyzed using Life Cycle Cost Analysis. It was found that all operation strategies can only generate Net Profit when the electricity cost is not subsidized. Combination of photovoltaic and MGT-TGS with power-match operation strategy had the highest Net Profit and was the simplest hybrid system. This was mainly because this system did not require battery that has high cost. Thus, this is the most optimum operation strategy when economic performance is considered.
\end{abstract}

\section{Introduction}

Stand-alone operation of distributed generation is important as a back-up power plant or a primary power plant for remote areas. Moreover, it also has an advantage in term of utilizing exhaust heat, and therefore it can be designed as a cogeneration system (CGS) or a trigeneration system (TGS) with enhanced performance. Photovoltaic (PV) that has a power output intermittency problem due to sunny/cloudy and day/night cycle can be integrated to this stable efficient technology [1]-[2]. This hybrid energy system will increase the penetration level of PV to the power generation market.

MGTs are attractive small scale prime movers because they emit less emissions especially NOx, compared to reciprocating engines and they are less costly compared to fuel cells [3]. Waste heat from MGTs can also be recovered easier because heat only need to be recovered at the exhaust gas stage. Moreover, high quality of exhaust heat $\left(>200^{\circ} \mathrm{C}\right)$ is also suitable for cooling purpose.

For utilizing heat, equipment including exhaust heat recovery system and an absorption chiller are needed. Since power and heat demand of buildings fluctuate throughout the day, PV-TGS hybrid systems are designed to satisfy these loads while considering its efficiency and cost. There are a few studies on the PV-TGS hybrid energy systems in [1]-[2], [4]-[5]. However, from literatures reviewed, there are no studies on the different operation strategies for a stand-alone PV-TGS especially when MGT is used as the prime mover.

Thus, the objective of this study is to propose the most optimum operation strategy of PV-TGS hybrid energy system when economic performance is considered.

\footnotetext{
a mfirdausb@ump.edu.my
} 


\section{Ambient Temperature Condition \& Energy Profile of the Selected Building}

Ambient air temperature is important as the input of the calculation especially for MGT. Ambient air temperature of Malaysia was used for the calculation. The hybrid energy system studied was designed to meet the energy demand of a group of 142 terrace houses. Each house is $6.5 \mathrm{~m}$ long and $19.8 \mathrm{~m}$ wide and covers a total area of $129 \mathrm{~m}^{2}$. Data for energy load for each house was adopted from a survey and study carried out in [6]-[7]. The power, heating and cooling demand of a single house are shown in Fig. 1 [8]. Power demand increases during day hours whereas cooling demand increases during night hours. Besides buildings loads, a particular length of water pipeline and power capacity of water pumps were also needed to calculate heat losses throughout the pipeline and power for water pumping.

\section{Model of the Hybrid Energy System}

\subsection{Hybrid Energy System Configurations}

A schematic diagram of the overall hybrid energy system for all cases is shown in Fig. 2. The core component is the MGT with a capacity of $30 \mathrm{~kW}$ or $65 \mathrm{~kW}$. At the power management side, PV and MGT produce electricity. Some of the electricity produced can be stored in the battery. At the heat management side, exhaust heat of the MGT is recovered by the heat exchanger, and it is used to cover water heating demand of the houses, and the rest is supplied to the absorption chiller. The absorption chiller then converts the heat to cooling energy to cover the cooling demand. Some of the cold water is also supplied to an inlet precooling (In.P-C) at the MGT air intake, to ensure MGT can generate power at the highest efficiency. A boiler is also used as a back-up heat supply.

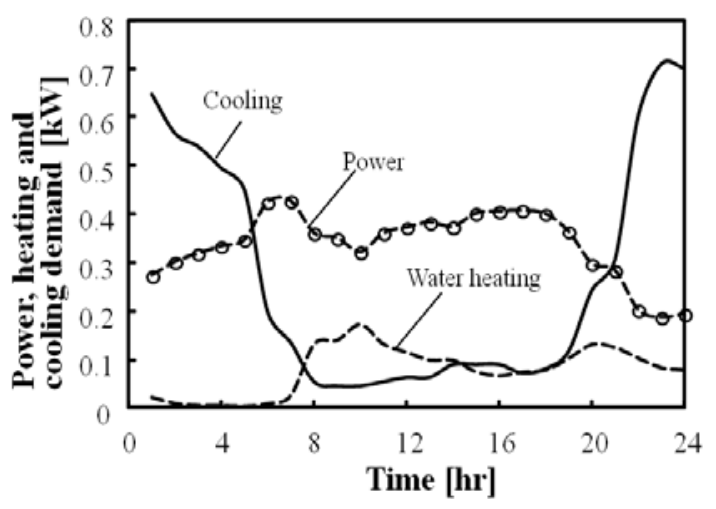

Fig. 1. Details of power, heating and cooling demand in a single day. [10]

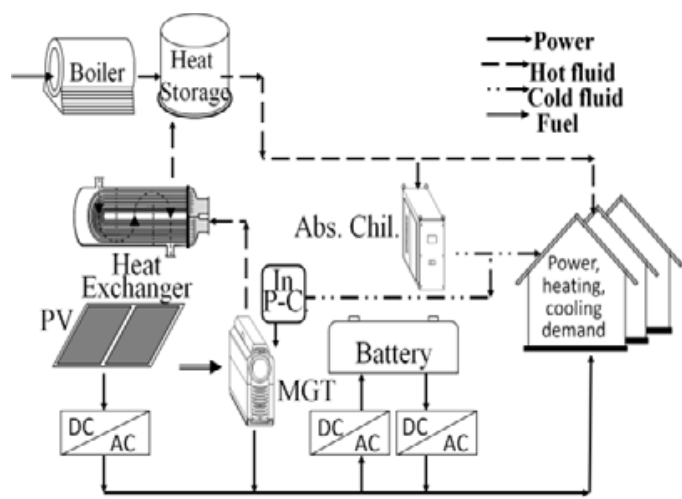

Fig. 2. Configuration of the overall hybrid energy system for all cases.

\subsection{Operation Strategies}

Three operation strategies studied are: (Case 1) base load operation strategy, (Case 2) power-match operation strategy, (Case 3) heat-match operation strategy. For Case 2, PV will cover power demand up to the maximum level during day time, and MGT will follow the rest of the power demand. Imbalance between the heat supply and demand can be controlled by the heat storage and back-up boiler. For Case 3, MGT will follow the total heating and cooling demand. Power demand will be covered by the combination of PV and MGT. Imbalance between power supply and demand can be controlled by the battery. It should be noted that MGTs are usually designed to have optimum efficiency at full load. Under partial load operation, their power generation efficiency will decrease rapidly. Thus, another good operation strategy is by using smaller MGT to run at base load, and the PV and battery will cover the power demand at peak load (Case 1). 


\subsection{Micro Gas Turbine Trigeneration System}

The MGT-TGS studied in the previous research in [8]-[10] that consisted of a recuperated single shaft MGT, an exhaust heat exchanger of tube-shell type and a single stage water-lithium bromide absorption chiller were used in the current study. Table 1 represents the basic specifications of the MGT, exhaust heat exchanger and absorption chiller. MGTs performance under partial load condition are important and were reported in [8] and [10].

\subsection{PV and Battery}

Polycrystalline silicon PV with power efficiency of $14.5 \%$ was considered in this study. Global radiation data in Malaysia was used as the input of the PV. Optimum area of the PV for each case was determined according to the power balance between the building load and the MGT output. Considering the new development, the lithium-ion was assumed to be used in this study and the charging-discharging efficiency was assumed to be $80 \%$.

\subsection{Economic Analysis of the Hybrid System}

Life cycle cost analysis was used to evaluate the economic performance of the hybrid energy systems. By considering time value of money, the value of money that will be expensed in the future is discounted to its present value. All cashflow throughout the life cycle will be calculated based on the present worth. Net Profit NP gained for 25 years of life cycle of the investment on the energy system can be calculated by the following equation:

$$
N P=P r_{P e}-\left(C_{e q}+C_{i n s}+C_{O \& M}+C_{r e p}-C_{\text {sal }}+C_{\text {fuel }}\right) \text {, }
$$

$C_{r e p}$ is the replacement cost for equipment that has life time less than 25 years [US\$], $C_{\text {sal }}$ is the salvage and market value of equipment at the end of their life time and the end of 25years of life cycle [US\$]. Table 2 shows parameters used for the calculation.

Table 1. Basic specifications of the MGT, Exhaust heat exchanger and Absorption chiller.

\begin{tabular}{|c|c|c|c|c|c|c|c|}
\hline & & $M G T-30$ & $M G T-65$ & Exhaust heat exchanger & & & \\
\hline $\begin{array}{l}\text { Exhaust } \\
\text { temperature }\end{array}$ & {$\left[{ }^{\circ} \mathrm{C}\right]$} & 273 & 309 & Effectiveness & {$[-]$} & 0.80 & 0.80 \\
\hline $\begin{array}{l}\text { Rated electrical } \\
\text { power output }\end{array}$ & {$[\mathrm{kW}]$} & 30 & 65 & Rated heat recovery & {$[\mathrm{kW}]$} & 56 & 105 \\
\hline Fuel input & {$[\mathrm{kW}]$} & 115 & 224 & Absorption Chiller & & & \\
\hline $\begin{array}{l}\text { Electrical } \\
\text { efficiency }\end{array}$ & {$[-]$} & 0.26 & 0.29 & $\begin{array}{l}\text { Cooling capacity } \\
\text { Heat medium input } \\
\text { capacity }\end{array}$ & $\begin{array}{l}{[\mathrm{kW}]} \\
{[\mathrm{kW}]}\end{array}$ & $\begin{array}{l}103 \\
150\end{array}$ & 103 \\
\hline
\end{tabular}

Equipment cost includes cost of MGT-CGS, PV, absorption chiller, boiler, heat storage, battery and inlet pre cooling. Operation and maintenance (O\&M) costs includes cost of MGT-CGS, PV, absorption chiller and battery.Annual O\&M cost for PV and battery was assumed to be $10 \%$ and $4.6 \%$ of its capital cost, respectively [11]-[12]. Present worth $P W_{x}$ of a uniform series of payment can be calculated as the following equations:

$$
\begin{gathered}
P W_{x}=P W F_{A U P} \cdot A U P_{x} \\
P W F_{A U P}=\frac{(1+i)^{n}-1}{i(1+i)^{n}}
\end{gathered}
$$

where $i$ is the interest rate [\%] which is $6.4 \%$. Replacement cost, salvage values for each equipment throughout the 25 years life cycle were also considered and can be calculated as the following equations:

$$
P W_{\text {reporsal }, x}=P W F_{S P @ S R} \cdot C_{\text {reporsal }}
$$




$$
P W F_{S P @ S R}=\frac{1}{(1+i)^{n}}
$$

Finally, fuel cost can be calculated with the same method of operation and maintenance cost. Price of Natural gas is shown in the Table 2.

\section{Results \& Discussion}

Power Output Conditions. Conditions of power demand and power output of PV and MGT in all cases are shown in Fig. 3. Results for Case 1, Case 2, and Case 3 are shown in Fig. 3a, Fig. 3b and Fig. 3c, respectively. As shown in Fig. 3a, MGT only supplied power for the buildings at base load, PV with the support of battery supplied power at peak load. Fig. $3 \mathrm{~b}$ shows that MGT operated at wide range of partial load in power-match mode. It covered total power demand during night time and support PV during day time. Since MGT followed the heat demand in Case 3, its power generation condition also varied. With the support of battery, surplus power during night time can cover insufficient power during day time.

Table 2. Parameters used for the life cycle cost analysis.

\begin{tabular}{|c|c|c|c|c|c|}
\hline & & & Salvage/Market & & \\
\hline Energy price & & & Value & (depreciation rate) & \\
\hline Natural gas & $\mathrm{US} \$ / \mathrm{m} 3$ & 0.197 & MGT-CGS* & $\% /$ year & 9 \\
\hline Electricity & US\$/kWh & 0.115 & AB.C & $\% /$ year & 5 \\
\hline Initial cost (Overnight) & & & PV & $\% /$ year & 3.2 \\
\hline MGT-CGS & $\mathrm{US} \$ / \mathrm{kW}$ & 1300 & Battery & $\% /$ year & 5.3 \\
\hline AB.C & $\mathrm{US} \$ / \mathrm{kW}$ & 300 & Boiler & $\% /$ year & 6.0 \\
\hline PV & $\mathrm{US} \$ / \mathrm{kW}$ & 3210 & Lifetime & & \\
\hline Battery & US\$/kWh & 1500 & MGT-CGS & year & 10 \\
\hline Heat Storage & $\mathrm{US} \$ / \mathrm{m} 3$ & 5500 & AB.C & year & 20 \\
\hline Boiler & $\mathrm{US} \$ / \mathrm{kW}$ & 90 & PV & year & 25 \\
\hline Inlet precooling & $\mathrm{US} \$ / \mathrm{kW}$ & 20 & Battery & year & 15 \\
\hline$O \& M \cos t$ & & & Boiler & year & 15 \\
\hline MGT-CGS & US\$/kWh & 0.01 & Exchange rate & $1 \mathrm{US} \$=\mathrm{RM} 3$ & \\
\hline AB.C & $\mathrm{US} \$ / \mathrm{kWh}$ & 0.001 & & & \\
\hline
\end{tabular}

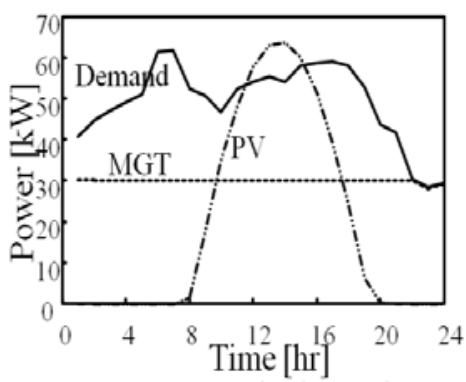

(a) Case 1 (Base load operation)

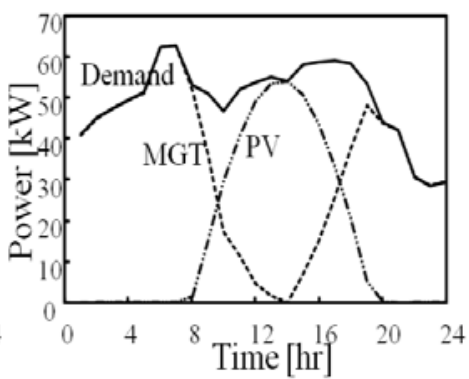

(b) Case 2 (Power-match operation)

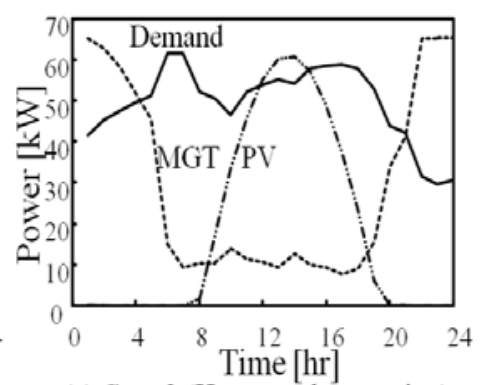

(c) Case 3 (Heat-match operation)

Fig. 3. Conditions of power demand and power output of PV and MGT in all cases. 
Economic Performance. Results on the economic performance of the hybrid system are shown in Fig. 4. White and grey bars show Life Cycle Net Profit when the electricity price are subsidized and unsubsidized, respectively. When the electricity price was highly subsidized, none of the hybrid system can give Net Profit throughout the 25-year life cycle time. Even the simplest MGT-TGS without PV cannot generate Net Profit. However, when the unsubsidized price of electricity was considered, all hybrid systems show positive Net Profit, especially power-match operation strategy.

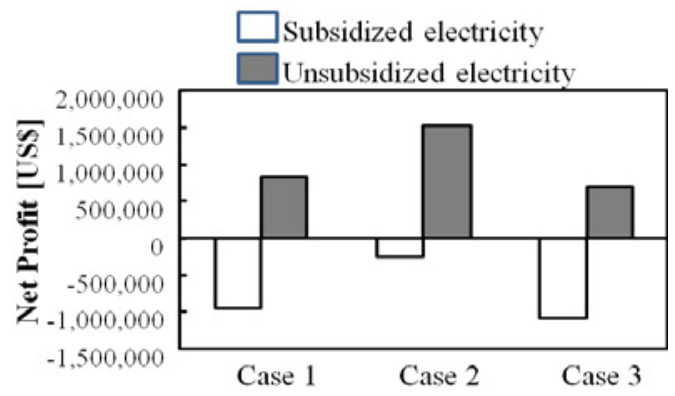

Fig. 4. Comparison of Net Profit of Hybrid Energy Systems for all cases.

\section{Conclusions}

All systems can only generate Net Profit at the end of 25 years life time when unsubsidized electricity price was considered. Power-match operation strategy had the highest Net Profit compared to other operation strategies. This is because the system did not require a battery whose price is usually high. Thus, in terms of economic performance, power-match operation strategy is the most optimum solution compared to other operation strategies.

\section{Nomenclature}

\begin{tabular}{|c|c|c|c|}
\hline$A U P$ & Annual Uniform Payment, US\$ & $N P$ & net profit, US\$ \\
\hline C & cost, US\$ & $\operatorname{Pr}$ & profit, US\$ \\
\hline$i$ & interest, - & $P W$ & present worth, US\$ \\
\hline$n$ & life time, year & $P W F$ & present worth factor, - \\
\hline \multicolumn{4}{|c|}{ Subscript } \\
\hline$e q$ & equipment & rep & replacement (cost) \\
\hline ins & installation (cost) & sal & salvage value \\
\hline O\&M & operation and maintenance & $\mathrm{SP} @ \mathrm{~S}$ & payment or single return \\
\hline
\end{tabular}

\section{Acknowledgements}

The authors would like to thank the Ministry of Education for providing Research Grant under FRGS (RDU130133).

\section{References}

[1] J. M. Pearce, Expanding photovoltaic penetration with residential distributed generation from hybrid solar photovoltaic and combined heat and power systems, Energy 34, pp. 1947-1954, (2009).

[2] A. Nosrat, J. M. Pearce, Dispatch stratergy and model for hybrid photovoltaic and trigeneration power systems, Appl. Energ. 88, pp. 3270-3276, (2011).

[3] F. Basrawi, T. Yamada, K. Nakanishi, Performance evaluation of micro gas turbine cogeneration system at sewage treatment plant, Trans. of the JSME (Part B) 76, pp. 1661-1670, (2010).

[4] A.G. El-Sayed, S. Obara, Energy supply characteristics of a combined solar cell and diesel engine system with a prediction algorithm for solar power generation, J. of Pow. and Energy Sys. 4, pp. 27-38, (2010).

[5] S. Obara, A.G. El-Sayed, Compound microgrid installation operation planning of a PEFC and photovoltaics with prediction of electricity production using GA and numerical weather information, Int. J Hydrogen Energ 34, pp. 8213-8222, (2009).

[6] T. M. I. Mahlia, P.L. Chan, Life cycle cost analysis of fuel cell based cogeneration system for residential application in Malaysia, Renew and Sust. Energ. Rev. 15, pp. 416-426, (2011). 
[7] T. Kubota, S. Ahmad, A field survey on usage of air-conditioners and windows in terraced house areas in Johor Bahru City, J. of Env. Eng. 608, pp. 81-87, (2006).

[8] F. Basrawi, T. Yamada, S. Obara, Theoretical analysis of performance of a micro gas turbine co/trigeneration system for residential buildings in a tropical region, Energ. and Buildings $\mathbf{6 7}$, pp. 108-117, (2013).

[9] F. Basrawi, T. Yamada, K. Nakanishi, S. Naing, Effect of ambient temperature on the performance of micro gas turbine with cogeneration system in cold region, Appl. Therm. Eng. 31, pp. 1058-1067, (2011).

[10] M.F.B. Basrawi, T. Yamada, K. Nakanishi, H. Katsumata, Analysis of the performances of biogas-fuelled micro gas turbine cogeneration systems (MGT-CGSs) in middle-and small-scale sewage treatment plants, Energy 38, pp. 291-304, (2012).

[11] A. Goodrich, T. James, M. Woodhouse, Residential, commercial, and utility-scale photovoltaic $(P V)$ system prices in the United States: current drivers and cost-reduction opportunities, NREL, p. 10, (2012).

[12] Electric Power Research Institute, Electricity Energy Storage Technology Options: A white paper primer on applications, cost, and benefits, E. S. 20, pp. A39, (2010). 